\title{
The Australian Head of State: Putting Republicanism Into the Republic
}

\author{
Harry Evans
}

\begin{abstract}
reasonably detached observer could be forgiven for thinking that the Australian republican movement is floundering. The arguments against sharing a nominal head of state with another country, which is now a member of a foreign quasi-federation, seemed so irresistible. Why does the movement fall so far short of the degree of popular support required to carry the change? A large part of the explanation is provided by a lack of coherence in the official republican movement, which is illustrated by the head of state issue. 'Having proclaimed that the monarchy must go, and that we must have an Australian president, the movement immediately founders on the question of how the replacement is to be chosen. The response of a large majority of Australians, according to the polls, is that they want to elect a president (The Bulletin, 1 August 1995, p.28). The official republicans recoil in horror from such a suggestion, resort to irrational arguments against it, and speak of the need to re-educate the public (Byers, 1995). ${ }^{2}$ It has to be explained to the people that the change is being made in such a way as to avoid changing the system of government: an odd argument for any kind of reformers attempting to persuade people to change anything. Never has there been a republican movement which wanted to replace a monarchy with something designed to look as much as possible like a monarchy.
\end{abstract}

\section{Republican Culture}

The problem is that official republicanism is no more than a nationalist and antihereditary movement to remove the British monarchy from Australia. It does not seek to foster or to build upon a republican culture. Historically, there have been two essential ingredients of republican theory and practice: institutions so structured as to provide a balanced system of government capable of avoiding the growth of monarchical power, and a reliance on the people as a whole as the only repository of sover-

\footnotetext{
${ }^{1}$ The conclusions of the official movement are contained in a statement by the Prime Minister (Keating, 1995), which is based on the Report of the Republic Advisory Committee (1993), which in turn is largely based on Winterton (1986).

2 'A president must not be politicised', The Australian, 5 July 1995. It is ironic that two of the greatest defenders of the official republic are knights of the realm: Sir Maurice Byers and Sir Zelman Cowen. The Primate of the Anglican Church has also rallied to the then Prime Minister: 'Church leader backs Keating republic model', The Sydney Monuing Herald, 4 July 1995.
}

Harry Evans is Clerk of the Australian Senate. 
eignty. A republican culture is one which recognises these central tenets of republicanism, and seeks to build upon them. Official Australian republicanism, however, is characterised by a neglect of questions of institutional structure and constitutional balance, and by a positive aversion to involving the people in goverument to a greater extent than they are now involved. It is in relation to the head of state issue that these characteristics are most clearly exposed.

The absence from official republicanism of a republican culture is maintained by an avoidance of serious historical or theoretical analysis. A little such analysis reveals the necessary elements of such a culture.

The idea that the absence of monarcliy may be a necessary, but is not a sufficient, condition to constitute a republic is far from new. The reader has to get well into the ancient Roman Cicero's treatise De Re Publica before finding the statement that the holding of an office of state for life is incompatible with res publica, which by definition is a partnership belonging to the whole community. The essence of res publica lies not in the absence of a king, but in institutional arrangements that maintain the partnership and avoid anybody using the state to dominate everybody else.

The founders of the first modern republic, the United States of America, might be thought to have had a ready-made republican culture on which to build. Before they broke from Britain, the colonies were de facto self-governing republics only nominally under the crown; effective power was held by assemblies elected on wide franchises, and two colonies even elected their own govennors. The founders drew up their new constitution, however, against a background of demonstrated failures of the republican state governments. These failures, manifest in one case in armed rebellion and war, were attributed to the weaknesses identified by Cicero: domination of government by factions and absence of balanced institutional structures. Not just any union, but a well-constructed union, was required to provide republican remedies against the diseases common to republics (Madison et al., 1787:1970, 10:41-8; 51: 263-7).

The Australian founders were more republican than their current would-be successors. Although they constructed their union under the British crown, they embraced the salient features of republican government, even adopting the name 'Commonwealth', the English equivalent of res publica and of the latinate 'republic'. They had a keen appreciation of the importance of well-designed institutions. Thus, they readily accepted the foreign model of federalism as the institutional basis of the Australian union. Federalism for them encompassed such institutional devices as specified central powers, equal representation of the States in the Senate and coordinate powers in the two houses of parliament, all un-Britislı innovations." They de-

\footnotetext{
${ }^{3}$ Sir Richard Baker, the leading federalist among the founders, reminded his colleagues of the foreign nature of the federal system, and also referred to responsible govenument as a 'British sham': Convention (1897), Sydney: 785-7.

${ }^{4}$ Remarks by Sir Samuel Griffith (quoted by Sir Riclarrl Baker), Dr Jolun Cockburn, Mr John Gordon and Sir Richand Baker, Convention (1897) Adelaide: 28, 326, 340; Sydney: 784, 789. Although the pow-
} 
voted much of their debates to the shape and relationships of institutions. They were also good republicans in relying on the ultimate power of the people: both houses of the parliament were to be directly elected, and the new constitution would be approved by, and amendable only by, referendum. The only deficiency in Australia's republican culture may be seen not in accepting the British crown but, on one view, in having self-government handed down from above before federation instead of building it from below, as had largely occurred with the American colonies. Federation itself, however, was an indigenous growth with strong popular participation.

The head of state issue is greatly illuminated by bringing to bear upon it the essential republican principles of sound institutional design and ultimate popular control.

\section{The Head of State and Institutional Design}

Some have suggested that we do not need a head of state (Republic Advisory Committee, 1993:47-51). Parliament after each election could elect the ministry, which would remain in office until the next parliament is elected, and if necessary could elect a new ministry in the course of a parliament. But this would mean that the prime minister or premier would become the de facto head of state. There would also be the question of whether lower houses should be dissolvable within their term, and, if so, who is to exercise the dissolution power and low its misuse by a prime minister or premier is to be restrained. Most people would agree that, if we are to retain the responsible government, or cabinet, system, whereby the executive govenument is carried on by a ministry having the support of the lower house, a constitutional umpire will be needed, holding the powers currently held by the Governor-General or some modification of them, to act as a final arbiter in situations in which the lower house is not able to constitute or support a ministry or the ministry seeks to subvert or bypass the processes of responsible government.

The official republican movement, represented by the previous government's 'preferred option', embraces the 'minimalist' position of changing the head of state with the aim of little or no change to the system of govenument. This is thought to rule out an elected president. The contradiction in calling this position 'republican' has already been noted: it is intended to provide a sort of indigenous, non-hereditary constitutional monarch. It is thought that the glost of the monarch should remain behind, rather like the Cheshire cat's smile, and that without this remuant our system of govenument must fail. The great republicans of the past, such as Tom Paine, would have found this determination to maintain the sharlow of monarchy as even more ludicrous than real monarchy (Paine, 1776/1986:80-1).

The foundation of this position is that an appointed presiclent will most closely resemble the appointed Govenor-General. The latter is de facto appointed by the prime minister alone; the favoured 'minimalist' method is for appointment by both houses of the parliament by a special majority. It is interesting to note that appoint-

ers of the House of Lords were not statutorily reduced until 1911, they were regarded in the late 19th century as limited by parliamentary practice. 
ment of a president by the prime minister alone, although originally proposed by $\mathrm{Mr}$ Keating on the ABC's Lateline (15 September 1993), is not contemplated and is regarded as obviously unacceptable. Presumably, this is because it is thought that a president should not be merely the creature of the prime minister, and that the role of president requires greater independence. This appears to be the sole concession of the 'minimalists' to republicanism properly so called, a small concession to the idea of balanced government. It is also notable that appointment by a simple majority of both houses is not favoured because it is thought that this would not be different from appointment by the prime minister. This is an admission of the real major problem with our system of govenument: excessive concentration of power in the hands of the prime minister, and prime ministerial control of the lower house.

The different method of appointment which is contemplated, however, would be likely to lead to a different result and to change the system of government, contrary to the stated intention. The favoured system of nomination by the prime minister and approval by a two-thirds majority of both houses means that the prime minister, who now alone appoints the Govennor-General, would have to gain the approval of at least the other major political party in parliament for the prime ministerial nomination. This means that the prime minister would have to put forward a nominee acceptable to the other major party, which implies that consultations would take place before the nomination is made. Consultations among politicians lead to deals. The deal may be for a candidate acceptable to both parties and not likely to offend any major strand of opinion in either party. A lowest-common-denominator effect could well set in. Recent appointees as Governor-General might not have passed muster in such a party agreement. A political deal can also take the form of a trade-off. An opposition may well accept the government's nominee on the basis of some returned favour. The deal could be: 'We do not really like your presidential nominee, but we will support the nomination if you will do something in return for us.' Political negotiations also notoriously tend to leak. The way in which the presidential nominee has been selected would inevitably become known to the public. The deals would be explained in the press. The selection process would then be looked upon unfavourably by outsiders, leading to a demand to replace this unsavoury process with direct election.

Regardless of whether this forecast would be likely to prove accurate in all respects, the point is that the different method of selection favoured by the 'minimalist' option would not leave the system of govenument as it is.

Contrary to the 'minimalist' position, a strong case can be made out that a directly elected president would constitute the least change from the current system of govenment. It is a question of constitutional design. The current system of constitutional monarchy and responsible cabinet government centres on a head of state, the monarch, who is independent of the parliament. Apart from occasions of revolution, the parliament does not choose the monarch; the crown as an institution is separately constituted. The theory of constitutional monarchy envisages that the monarch will enjoy wide public support, shoring up the independence of the crown. GovenorsGeneral and governors, as representatives of the crown, were also originally supposed to be independent of parliament. The change to de facto appointment by the prime 
minister or premier may have undermined that independence, but the appointees may still be supported by the aura of the crown. But parliamentary appointment of a president, even by a special majority, would remove that independence of the head of state. The prime minister's freedom of choice would be removed, but so would any remaining aura of the crown. The head of state would be, and would be seen to be, dependent on the parliament, or, in reality, on the two major parties. The proposal to have the president removable by the parliament without stated cause (Keating, 1995) would greatly reinforce that dependence.

A directly elected president, however, would provide a republican replacement for the crown, with independent public support and no dependence on parliamentary support for appointment or continuance in office.

Whenever the possibility of election is mentioned, the oflicial republicans raise the question of the powers of the office (Republic Advisory Committee, 1993:72-3). It is pointed out that the Governor-General possesses great powers under the Constitution, principally the power to appoint and dismiss ministries. It is claimed that these powers could not safely be entrusted to an elected president. This too is a curious argument from persons who call themselves republicans. The powers are regarded as safe when vested in an appointee of the prime minister or a nominee of the prime minister approved by a deal with the other major political party, but they may not be safely vested in a person independent of the ministry and the parliament and endorsed by the electorate. Surely it is more rational to argue that the extensive powers of the office require the independence and popular support of election. This contention is supported by the history of constitutional government. Extensive powers require election; appointed bodies can have only limited powers. Thus, the United States Senate, with its great constitutional powers, was changed from an appointed to an elected body, while the hereditary and appointed House of Lords had its powers taken away.

Even if a president is to perform only the role of the Governor-General, holding great powers but exercising them according to conventions, this role would seem to require the independence and public support of direct election rather than dependence on the politicians. The Govennor-General's role may be regarded as that of an umpire, largely observing the political game and intervening only at times of difficulty to ensure compliance with the rules. The role of a Governor-General becomes crucial when responsible govenment ceases to work: when a lower house is incapable of supporting any ministry, when a prime minister refuses to resign or advise an election upon loss of the support of the lower house, and in similar situations. Many such cases have occurred, including recent cases in Australia. ${ }^{5}$ If vice-regal representatives have been successful in resolving these situations, it is because it is understood that they perform the role of the crown. An effective republican umpire to resolve such

${ }^{5}$ Following the Tasmanian general election of 1989 , the govenor rejected a request from the premier for a new election and required the leader of the opposition to provide firm evidence of his ability to form a stable coalition government. Many other cases are set out in Evatt and Forsey (1990). 
situations requires independence and public support in substitution for the residual prestige of the crown.

The powers of the Govenor-General are exercised in accordance with the practices, precedents and conventions associated with responsible government. In a republic, an independent president is likely to observe them more scrupulously than one beholden to the politicians.

In short, considerations of institutional design, including the contention that we must follow the scheme of the existing system as far as possible, indicate that a president dependent on the major parties is the most unsound option, and that direct election achieves both of the aims of institutional balance and as little change as practicable to the existing system.

\section{The Head of State and Popular Sovereignty}

The official, 'minimalist', position, by rejecting so emplatically the option of an elected president, creates at the heart of the republican movement an enormous democratic deficit, which places it under a severe handicap, particularly in persuading the electors.

It is said that we must liave an indigenous head of state to be a symbol of the nation, to represent Australia and its people, and to represent the people to themselves. It is not clear how such an exalted role can be performed by any officeholder unless the office has a strong and close link with the people, or how such a link can be attained except through popular election. It is highly unlikely that such a role could be performed by a person appointed by the politicians. Governors-General, without the handicap of being appointed by subterranean political deals, have not been able fully to perform such a task; one has the feeling that in recent years they have been less conspicuous to the people than in the past.

It is also said that popular election would lead to a party contest and the election of a party politician, and that a person selected by this process would be incapable of properly performing the role of national symbol or that of constitutional umpire. It is somewhat contradictory so to imply that an elected president would follow the partisan interests or instructions of the party which nominated and campaigned for him or her, while it is supposed that a president appointed as a result of a deal between the major parties would not suffer from a similar, and more debilitating, dependence.

It is a mon sequitur to claim that a president elected after a party contest would be incapable of performing the required role. To a certain extent, the function of representing the nation as a whole is performed by the prime minister of the day, who is invited to make inspiring speeches and to launch great events, perhaps more often than the Governor-General. A party politician elected to the presidency, and without the responsibility of actually exercising executive power, would be more capable in that regard than a prime minister. Such a president would be likely very quickly to become a former party politician transformed by the high office. This occurred, after all, with Mr Hayden and his politician-predecessors to a large degree.

In any case, it does not follow that the electors would vote for party politicians. The unstated premise here is that the electorate would be incapable of distinguishing 
between an election to choose a government to carry out favoured policies and an election to choose a head of state. It is more likely that the voters, if presented with the choice of non-party candidates, would forsake the established political parties and return persons without partisan attachments. It would be important to ensure that the right to nominate candidates is not confined to political parties in or out of parliament. The political parties would then be likely to follow the signals of the voters and nominate or support attractive non-party candidates. In order to facilitate this effect, it may be desirable to restrict campaign spending by political parties in presidential elections.

It also does not follow, as has been repeatedly stated by exalted personages in recent times, that an elected presidency would preclude the choice of distinguished persons. If candidates really are distinguished, there is every likelihood that opinionleading groups would support them and that the people would vote for them.

\section{Other Republics}

These contentions receive some support from the practices of the established republics of the world.

The number of stable republics with constitutions that have functioned for reasonable periods without major unconstitutional episodes is relatively small, but so is the number of stable, democratic constitutional monarchies. Thirteen republics have been stable for the past 25 years or more under their current constitutions: Austria, Botswana, Finland, France, Germany, Iceland, India, Ireland, Israel, Italy, Singapore, Switzerland and the United States of America. Four of these countries have executive presidencies. The United States has a pure executive presidency; Botswana, Finland and France have hybrid systems in which the government is carried on by ministers in the legislature but the president also exercises executive power. Switzerland has a separately constituted, but not directly elected, collegiate executive, quite different from a parliamentary cabinet.

Of the remaining eight countries with parliamentary cabinet systems of government, four have directly elected presidents who perform a role similar to that of Australia's Governor-General. In Singapore and Ireland, party nominees have been elected as president, although Singapore has had only one presidential election since changing to direct election, and at the last Irish election a non-party person was returned, which may well inspire a cliange of practice in that country. In Iceland and Austria, it has been the practice to elect distinguished persons who may or may not be supported by political parties. The current president of Iceland is regarded as so distinguished that she has been re-elected on several occasions unopposed. Iceland also provides a refutation of the claim that the combination of an elected president and a cabinet system of government requires codification of the powers of the head of

\footnotetext{
${ }^{6}$ Principally the other kuight of the realm, Sir Zelman Cowen: see his remarks reported in 'State a republic too, says ex-G-G', The Mercury, 12 July 1995.

${ }^{7}$ Although formerly a member of the Labour Party, President Mary Robinson did not stand as a candidate of that party.

8

President Vigdis Fumbogadottir, a former theatre director.
} 
state: the Icelandic constitution contains as little specification of those powers as Australia's.

The remaining four countries have cabinet systems of government with appointed presidents. All of these countries drew up their constitutions in the aftermath of World War II, and had historical reasons for avoiding elected heads of state. The constitution of the German Federal Republic was drafted amid the ruins of the war; since presidential elections were associated with Hindenburg and the appointment of Hitler, it is not surprising that the precedent of the Weimar Republic was not followed. India, which established its constitution immediately after a period of terrible communal violence, likewise eschewed presidential elections, which could have set one community against another. Israel in the same period was in a constant state of warfare, which made government by a single cliamber possessing all powers appear to be the only option. Italy in the post-war period was haunted by the memory of Mussolini, and therefore opted for collective (and weak) leadership. None of these countries offers useful parallels for Australia.

Making allowance for the necessarily small number of examples, it can be said that a cabinet system of government with a head of state who performs essentially similar functions to Australia's Govennor-General is compatible with popular election of that head of state. Such a combination does not necessarily involve the election of party politicians, but may also lead to the election of distinguished non-party persons.

\section{The Problem of the States}

The issue of the head of state arises at the State level, but with an additional difficulty. One of the greatest problems with State parliaments is that they are too small to support a proper system of cabinet government. With a house of fewer than 100 members, whell a ministry is appointed from the majority and a shadow ministry from the minority, there are few backbenchers left to undertake the parliamentary roles of monitoring executive activities and scrutinising legislation, particularly through a parliamentary committee system. It is politically very difficult to expand the State houses; indeed, there are pressures to reduce their size as a way of lessening the burden on the taxpayer (see Tasmania, Board of Inquiry, 1994).

It has been suggested that the federal liead of state could also act as the head of state of each of the States, just as the Govemor-General is in effect head of state of the Australian Capital Territory, and that States could share govenors (Winterton, 1986:107). Having to look after more than one jurisdiction, however, would place too great a workload on the officeholders, if they perform their duties diligently, and would violate the federal principle of the independent constitution of the States.

The suggestion that each of the States should have an elected governor, which is here submitted to be the appropriate constitutional arrangement if we are to retain parliamentary cabinet govenument, is likely to meet with the very strong objection that such an elected office would simply add to the burden on the taxpayer, especially if gubernatorial elections are to be held separately from partiamentary elections. But a solution exists that would solve both the head of state issue at State level and the problem of the small size of State parliaments. This is a scheme that could be under- 
taken as an experiment by one of the less populous States, such as South Australia or Tasmania. One advantage of federalism is that such experiments can be undertaken without affecting the whole country.

The houses of the parliament of the State which experiments with this reform would continue with their current composition, or with their membership marginally reduced if it is desired to make the change cost-neutral. At the same time as the lower house is elected, a governor would be directly and separately elected by the electorate. The governor would be the head of state as well as the head of government. This officer would conduct the executive government, and would appoint a small cabinet of ministers from outside the parliament. The parliament would perform the legislative functions of passing laws and scrutinising the operations of government. The simultaneous election of the governor and the houses, or the lower house if the upper house has different terms, would reduce the likelihood of serious deadlocks between the houses and the executive government. As each would be elected for a fixed term, there would be no power of dissolution and no early elections. Upper houses would perform their present scrutiny and review functions. It is suggested that the houses should have the ability to scrutinise, but not to veto, executive appointments. An executive veto of legislation could be overridden by a special majority of the houses.

This would not be the American system. There would be no mid-term elections to increase the likelihood of disagreements between legislature and executive, and it would not involve adopting the American party or electoral systems. Even if the current disciplined Australian party system remained in all its cohesion and discipline, this scheme would still be an improvement, because the legislature would be freer to perform the legislative functions and the choice of ministers would not be limited to the parliamentary members of the majority party. The scheme would amount to the adoption at the State level of the basics of the system which has been used with success in local govenment in some States for many years, whereby the mayor and council are separately but simultaneously elected. (On one view, an amendment of the Australia Act 1986 may be necessary to allow a State to adopt this system: see Waugh, 1996.)

If one of the small States undertook this experiment, we could assess whether we should be so fearful of changing the system of government as the official republicans suggest. It is suggested that, if adopted, this scheme would prove so effective that other States would follow suit, and it may even be adopted at the federal level. The system of government would then undoubtedly have been changed. There would be no doubt, however, that it would be thoroughly republican. We would also have followed in the footsteps of the founders by not being afraid to try a system new and foreign to our traditions, as was federalism, in order to provide the country with an efficient as well as a truly republican constitution.

\footnotetext{
${ }^{9}$ See the statement by Justice Brandeis, quoted in Winterton (1986:107); Kasper (1993).

10

A similar scheme has been suggested by Mautyı Webb in O'Briell and Webb (1991:327-8).

11

Other commentators who have questioned the official orthodoxy about electing a president include McGuinness (1993), Rathapala (1995) and Irving (1995).
} 


\section{A Head of State for Australia}

We are constantly reminded by the official republicans that the issue is all about an Australian head of state: we must have a head of state to suit Australia.

But this premise does not lead to the conclusion that the head of state must resemble as closely as possible the British constitutional monarch. On the contrary, the institution of an Australian head of state should build upon the nascent republican culture of Australia, as exemplified by the founders of the federation, with their emphasis on institutional design and on popular participation. Building on that foundation entails an elected head of state.

\section{References}

Byers, Sir M. (1995), 'Presidential poll will lead to chaos', The Australian, 5 July.

Convention (1897), Debates of the Australasian Federal Convention, Adelaide, Syduey, SA and NSW Govemment. Printers.

Evatt, H. \& E. Forsey (1990), Evatt and Forsey on the Reserve Powers, a reprint, with a lengthy introduction by Dr Eugene Forsey, of his The Royal Poreer of Dissolution of Parliament in the British Commonwealth (1943) and Dr H. V. Evatt's The King and His Dominion Govenors (Legal Books, Sydney, 1936).

Inving, H. (1995), 'Why shouldn't we choose our head of state', The Australian, 14 March.

Kasper, W. (1993), 'Competitive Federalism: May The Best State Win', pp.53-69 in Restoring the True Republic, Centre for Independent Sudies, Sydney.

Keating, P. (1995), 'An Australian Repulblic, 'The Way Folward', statement by the Prime Minister, 7 June, House of Representatives Delaztes. 1434-41.

Madison, J., A. Hamilton \& J. Jay (1787, 1970), The Federalist Papers, Dent, London.

McGuinness, P. (1993), 'President needs proper powers', The Australian, 14 May.

O'Brien, P. \& M. Webb (eds) (1991), The Executive State: WA Ins. and the Constitution, Constitutional Press, Perth.

Paine, T. (1776/1986), Common Sense, Penguin, Harmondsworth.

Ratnapala, S. (1995), Westminster Democracy and the Separation of Powers: Can they Coevist?, Canberra, the Senate (Papers on Parliament No. 26).

Republic Advisory Committee (1993), An Australian Republic - The Report, AGPS, Canberra.

Tasmania, Board of Inquiry (1994), Report of the Board of Inquiry into the Size and Constitution of the Tasmanian Parliament, appointed by the Tasmanian govenument, Tasmanian Govenment. Printer, Hobart.

Waugh, J. (1996), 'Austalia's State Constitutions, Reform and the Republic', Agenda 3(1): 59-69.

Wunterton, G. (1986), Monardyy to Republic: Austadian Republican Govenument (1st edition), Oxford University Press, Melbourne (reprinted with additions in 1994). 